\title{
ABBOTT AWARDS IN ANAESTHESIA FOR 1974-75
}

This year 20 residents, training in 14 different university departments of anaesthesia, received Abbott Awards of $\$ 500$. These Awards are offered annually by Abbott Laboratories, Limited, to assist residents in training. The recipients of these Awards are chosen by the Heads of the university departments concerned. The following are the names of those who recently received Abbott Awards for 1974-75:

\begin{tabular}{|c|c|}
\hline DR. J. SwmERSKI & University of Western Ontario \\
\hline Dr. G. Morton & University of Alberta \\
\hline Dr. J-P. TÉtreault & Université de Sherbrooke \\
\hline DR. M. KOPACZ & McMaster University \\
\hline DR. M. MARGISON & Dalhousie University \\
\hline DR. T. KEON & University of Ottawa \\
\hline DR. W. Pope & University of Manitoba \\
\hline DR. S. WALJI & University of Saskatchewan \\
\hline Dr. A. Harper & University of Calgary \\
\hline Dr. Fong-Mei Chow & McGill University \\
\hline Dr. JoHn Hewson & McGill University \\
\hline Dr. W. Robinson & University of British Columbia \\
\hline Dr. J. BerezowsKyJ & University of British Columbia \\
\hline Dr. R. KLAUTKY & University of Toronto \\
\hline Dr. H. Chinyanga & University of Toronto \\
\hline DR. P. Limoges ） & Université de Montréal \\
\hline DR. M. Ouellette $\}$ shared & Université de Montréal \\
\hline DR. Y. BROSSARD & Université de Montréal \\
\hline Dr. J. Allard & Université Laval \\
\hline DR. J-P. MOREnCY & Université Laval \\
\hline
\end{tabular}

